\title{
Sagu Sabu Program to Improve Teachers' Coursebook Writing Skills
}

\author{
Rudi Hartono ${ }^{1}$, Bambang Purwanto ${ }^{2}$, Seful Bahri ${ }^{3}$ \\ \{rudi.hartono@mail.unnes.ac.id ${ }^{1}$, bambangpurwanto@mail.unnes.ac.id² \\ seful.bahri@mail.unnes.ac.id ${ }^{3}$ \\ English Department, Universitas Negeri Semarang ${ }^{1}$, English Department, Universitas Negeri \\ Semarang ${ }^{2}$ \\ English Department, Universitas Negeri Semarang ${ }^{3}$
}

\begin{abstract}
Creativity and innovation are the hallmarks of 21 st-century teachers. Teachers are required to actively foster their creativity so that innovative teacher products will emerge as works that are beneficial to themselves, schools, society, the nation, and the country. A number of teaching staff or teachers in Indonesia have not thought creatively even though the government has provided opportunities for them to be creative in various fields, such as writing coursebooks, developing teaching materials, making learning media, and increasing other academic productivity. One of the weaknesses they have is that they are not productive in writing coursebooks or textbooks, even though writing books is an integral part of teaching and learning activities. Increasing the productivity of textbooks for teachers through the Sagu Sabu program is an effective effort that greatly helps teacher achievement in schools because so far teachers have been passive writing textbooks for their own needs, even for mass publication efforts. The purpose of this study is to increase teacher productivity in writing subject books. This study uses a one-cycle action research type. This involved 10 teachers of SMAN 12 Semarang City. The research instruments used were two SurveyMonkey application questionnaires, field notes, and FGD. An action to increase teacher productivity in writing coursebooks is the Sagu Sabu program. Based on the research data obtained, it is known that before the Sagu Sagu program was implemented, there were no teachers who wrote coursebooks at all $(0 \%)$ while after the program was implemented there were 4 teachers who succeeded in writing coursebooks, even though the percentage was very high. It was still very small $(30.76 \%)$ when compared to the total number of participants. Besides, based on the responses to a questionnaire about the Sagu Sabu program, $84.62 \%$ agreed that this program is very important to increase teacher creativity in writing course books and lead them to become productive writers. The conclusion is that the Sagu Sabu program is very effective in helping increase teacher productivity in writing coursebooks so that teachers can have innovative works that are very beneficial for themselves and the school's reputation. Therefore it is highly recommended for policymakers in schools and the government to make this program a success so that more and more teachers will be productive in writing coursebooks.
\end{abstract}

Keywords: Teachers' productivity, Sagu Sabu, writing skill, coursebook. 


\section{Introduction}

Teacher activities and creativity that produce innovative products are highly expected at this time [1]. This is one of the characteristics of the 21st-century teacher. Currently, there are still many teachers who have not been productive in developing their careers, even though there are many ways that can be done, for example making textbooks for their needs at school or publishing them to many people [7]. How do you know if someone is productive? We can see from the amount of productivity he has generated so far. How can productivity be measured? To measure productivity in education is indeed not easy, it is not as easy as measuring productivity in the private sector. Measuring productivity in education uses new student input and graduate output as measures. By auditing incoming students and graduates, education productivity will be measured. On the other hand, teacher resources, school administrators, facilities, and finance expenditures are determining factors that influence the school productivity [4]. Regarding teacher productivity in book publication, it can also be measured from the input and output factors of the teacher's resources. The more often they attend book writing training, have good writing competence, want to write books, need points for promotion, have a sense of care for the development of knowledge, want to obtain additional sources of welfare, the more productive teachers will be [7].

What is a coursebook? Trimansyah [17] defines that the subject books we mean in this study are books that refer to the learning syllabus used in schools, so they are used as the main teaching media by teachers. So far, teachers only have handouts that they have made themselves as a collection of copied teaching materials. They do not write teaching materials in the form of course books. Why should they have their textbook writing skills? Although the government has provided many textbooks for teaching and learning activities in schools, teacher productivity in writing textbooks is still very important. The creativity book itself can become an enrichment and complimentary book, as a supporting book for the main book. With this productivity, it is hoped that teachers can be independent, do not depend on other sources, and can improve their welfare.

But what happened? Are teachers currently productive in writing their coursebooks? Many teachers cannot, do not dare, and do not have the will to write textbooks. Many teachers lack the motivation to become textbook authors. They lack self-confidence. Schools or institutions do not facilitate their efforts and facilitate them well. They don't know what to write and rely only on student workbooks they buy from publishers. Then they got into the habit of just copying from books or other sources and it seemed they had no chance at all to write textbooks.

Therefore, the purpose of this study is to increase teacher productivity in writing subject books. As a solution to increasing teacher productivity, we are introducing the One Book One Teacher program to be implemented. This program leads to active and productive teachers to write textbooks. The popular term used here is Sago Sabu (One Guru One Book) [8], [9], [10], [14]. This program has the potential for activities as an integrated program in preparing teachers to become professional course book writers. This can motivate and increase teacher productivity in developing learning materials into coursebooks [12]. Operationally in this study, we propose Sago Sabu as a coursebook writing program or other complimentary books for teachers who have important subject matter or ideas to write in printed books and e-books as a source or reference for teaching and learning activities in class or reading material. for students and the general public [6]. 
Related to the Sagu Sabu Program, Hartono [6] proposed eight steps in the delivery of this program that could lead teachers to become professional course book writers. The eight steps are as follows:

1) Introducing the procedure for writing coursebooks;

2) Prepare teaching materials that are by the lesson plans, syllabus, and current curriculum;

3) Writing the initial draft;

4) Checking the initial draft according to the content and rules of writing coursebooks;

5) Editing and revising the initial draft into the final draft;

6) Prepare a book cover and other additional page formats;

7) Send manuscripts to publishers;

8) Publishing manuscripts or doing self-publishing.

To have a good and standardized textbook, a writer must follow the writing process. There are five steps in the writing process: prewriting, drafting, revising, editing, and publishing [2], [18]. Look at picture 1 carefully. The first step is pre-writing. In this step we can carry out the following activities: 1) identify the audience, 2) define goals, 3) think, 4) discuss, 5) collect ideas, and 6) read/annotate, 7) free write, and 8) describe. At the drafting stage, we can put ideas on paper [19]. The second step is preparation. This step includes the sequencing of ideas and organization, rethinking, supporting concise word selection, audience/purpose. The drafting stage is the time for the writer to revise and peer review. In the drafting step, we can put the ideas on paper [19]. It is the command line to explain drafting. Draft or blur is writing that is made one time. When drafting, it's recommended that you write down whatever you think of related to the chapters or subsections you are putting together, of course - and don't edit while writing. The third step is editing. This step consists of editing grammar, punctuation, spelling, formatting, doing citations in the text, checking references, or bibliography. The position of the editing stage is very important and significant, so many writing experts recommend focusing on that stage because this position will greatly determine the final result of the writing. Watson [22] said: "Don't doubt yourself! Write what's on your heart. Write down what to write. Write down the things you would think of in bed at night if you didn't put them on the page". Don't worry about how it will be received; that part came during the editing process. Meanwhile, Trimansyah [18], [20] suggested things that need to be considered in editing. Four main aspects need our attention in the editing process: typographical errors, linguistics (order of sentences and paragraphs), the accuracy of data and facts, and legality (related to plagiarism) and appropriateness. The final step is publishing. This is the step of introducing the work to the public or users. In this step, a writer can publish his work in class, online, or publisher.

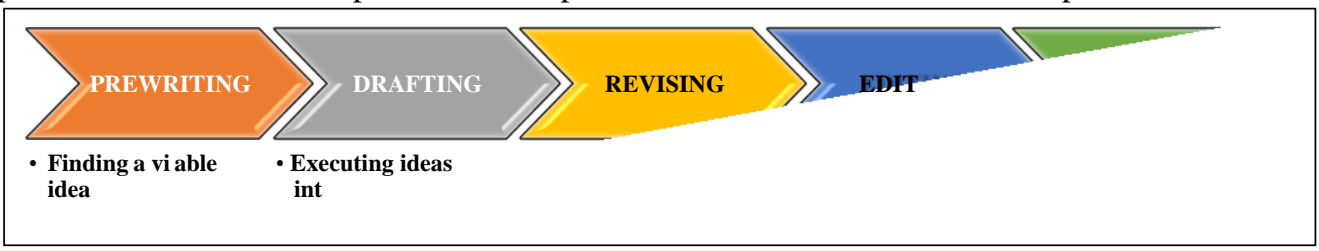

Fig. 1. Stages of Coursebook Writing Process

To get a good and complete textbook product, Collins [3] also provides some accurate and complete tips. It's like a surefire guide for writers. The tips are to commit to writing your book, what you should know about writing a book, researching your audience, getting new ideas for your book, settling on your book, deciding what kind of author you are, budget for selfpublishing your book, research your book, break your writing into chunks, interview experts for 
your book, stop researching, start writing your book, outline your book, set your book control ideas, set deadlines, have a dedicated writing room, write messy first drafts, thank you will make mistakes, manage your writing time, counter writer's block, track your progress, before editing your book, let it go, write your next draft, take a break from book writing, hire editors, hire correctors, format your book, get ready to publish your book, write a catchy title, get a great book cover, build a launch team, market your book, and know when you are at the end.

In connection with the work of teachers in this program, we prepare anatomy course books for them to do. The anatomy coursebook consists of four main sections: cover, introduction, text material, and preliminaries [11], [13, [16]. Furthermore, Rappahannock [15] suggests a more complete anatomy of a textbook or textbook: 1) Introduction or Introduction, 2) Foreword, 3) Author's Profile, 4) Table of Contents, 5) Preview of Chapter or Learning Objectives, 6) Introduction, 7) Applied Practice, 8) Chapter Summary, 9) Review Material, and 10) Endnotes and Bibliography. Some of the anatomies of this textbook can be applied or used in the coursebook.

Regarding the structure of a good textbook, Hartono [4] suggests the criteria for a good book.

These criteria can be clarified from the answers to the following questions:

1) Does the book help target students develop effective communication skills?

2) Does the book encourage cooperative learning?

3) Does the book provide awareness-raising activities for the discovery of linguistic features?

4) Does the book try to personalize the learning process by making students connect topics and texts with their own lives, views, and feelings?

5) Does the book contain various activities for students to use different learning strategies?

6) Does the book offer options to cater to student differences?

7) Does the book provide useful reference material (eg vocabulary lists, tape transcripts, answer keys, indexes, etc.?

8) Does the book include the use of computers and internet technology to support independent learning?

\section{Research Method}

To see an increase in teacher productivity in writing course books, we used a one-cycle action research design [5]. We only conducted one-cycle action research because with only one cycle the results of improvement were revealed. In conducting this research, there are six stages of the cycle: 1) checking teacher productivity before the Sago Sabu program, 2) collecting teacher productivity data using the SurveyMonkey application, 3) collecting, tabulating, and displaying initial data tables, 4) Application of the Sagu Sabu Program for Increasing the Productivity of Teacher Course Books 5) Checking Teacher Productivity after the Sagu Sabu Program, 6) Collecting, Tabulating, and Presentation of Final Data in Tables and Graphics, 7) Checking the impact and benefits of the Sago Sabu program by distributing questionnaires using the SurveyMonkey application, and 8) draw conclusions and make suggestions.

In this study, we involved 10 teachers as participants. To find out the teacher's response to the Sagu Sabu program and get the data, we distributed questionnaires using the SurveyMonkey application to all participants. In collecting this data, we use a Likert scale design. The questionnaire contains ten questions covering the teacher's experiences in writing course books. To check teacher responses to the benefits of the Sagu Sabu program, we also distributed questionnaires designed using the SurveyMonkey application. To observe teacher productivity, we conducted field observations by recording teacher activities in writing subject books on field notes. Besides, we also held focus group discussions to share their comments about the Sagu 
Sabu program and discuss their writing products through this program. All data are described qualitatively, then conclusions are drawn and given suggestions. To achieve the goal of the Sagu Sabu program, we set the research steps controlled month by month. The steps were organized by the researchers and school staff [7]. The steps were as follows: 1) Checking to need analysis, 2) Setting the Sagu Sabu program, 3) Designing a book according to the latest curriculum, 4) Implementing the Sagu Sabu program, 5) Monitoring the Sagu Sabu program, 6) Publishing the books, and 6) Evaluating the Sagu Sabu program.

To analyze the data for questionnaire 1 , a formula that is calculated automatically in the SurveyMonkey system is used, while the Likert scale formula is used to calculate the data for questionnaire 2. First, to calculate the response score of each respondent, we used the formula $\mathrm{T} x \mathrm{Pn}$. T means the number of respondents who answered while Pn means the Likert score choice. Second, to interpret respondents' assessment of the Sagu Sabu program, we use the formula\% Index = Total Score / High Score x 100. To see the score interpretation criteria, the following intervals are used:

1. Score $0 \%-19.99 \%=$ Strongly Disagree

2. Score $20 \%-39.99 \%=$ Disagree

3. Score $40 \%-59.99 \%=$ Don't know

4. Score $60 \%-79.99 \%=$ Agree

5. Score $80 \%-100 \%=$ Strongly Agree

\section{Findings and Discussion}

\subsection{Teacher's Experience of Writing Coursebook}

Table 1. Data of Teacher's Experience of Writing Coursebook

\begin{tabular}{|c|c|c|c|}
\hline \multirow{2}{*}{ No. } & \multirow{2}{*}{ Question } & \multicolumn{2}{|c|}{ Respondents (\%) } \\
\hline & & Yes & $\Sigma$ \\
\hline & I like writing coursebook. & 82 & 10 \\
\hline 2. & I have written a handout. & 28 & 10 \\
\hline 3. & I have written a coursebook. & 010 & 10 \\
\hline 4. & I have developed a handout into a coursebook. & 010 & 10 \\
\hline 5. & I have published my coursebook myself. & 010 & 10 \\
\hline 6. & My coursebook was published by a publisher. & 19 & 10 \\
\hline 7. & I have difficulties in writing a coursebook. & 91 & 10 \\
\hline 8. & I have ever taken part in coursebook writing training. & 37 & 10 \\
\hline
\end{tabular}


\begin{tabular}{lllll}
\hline $9 . \quad$ I must be able to write a coursebook. & 10 & 0 & 10 \\
\hline
\end{tabular}

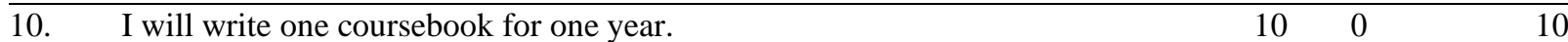

Table 1 describes the teacher's responses to the experience of writing subject books before the Sagu Sabu program. Based on the research, it was found that $69.23 \%$ of teachers did not like writing and $30.77 \%$ of teachers liked this activity, $30.77 \%$ of teachers had written handouts while $69.23 \%$ of teachers had not, $100 \%$ of teachers had written. , developing, and selfpublishing textbooks, $15.38 \%$ of teachers publish textbooks and $84.62 \%$ of teachers do not, $92.31 \%$ of teachers have difficulty writing textbooks, $38.46 \%$ of teachers receive textbook writing workshops, and $61.54 \%$ of teachers do not get it, $100 \%$ of teachers agree that they must be able to write and produce course books within a year. The findings from Table 1 have a close relationship with what some $\mathrm{Sagu} S \mathrm{Sabu}$ developers and practitioners found in real life that teachers are less experienced in writing course books and they agree that all teachers should have an inner motivation to make this effort [8], [9], [10], [14].

\subsection{Teachers' Responses on Sagu Sabu Program}

Table 2. Teachers' Responses on Sagu Sabu Program

\begin{tabular}{|c|c|c|c|c|c|c|}
\hline \multirow{2}{*}{ No. } & \multirow[b]{2}{*}{$\begin{array}{c}\text { Pernyata } \\
\text { an }\end{array}$} & \multirow[b]{2}{*}{$\mathbf{S}^{S}$} & \multicolumn{3}{|c|}{ Response/Score } & \multirow[b]{2}{*}{$\begin{array}{r}\mathrm{S} \\
\mathbf{T S} \\
\end{array}$} \\
\hline & & & $\mathbf{S}$ & $\mathbf{T}$ & $\mathbf{T}$ & \\
\hline & & 5 & 4 & $\mathbf{3}$ & 2 & 1 \\
\hline 1. & $\begin{array}{l}\text { Sagu Sabu is a very important program to motivate teachers } \\
\text { towrite coursebooks. }\end{array}$ & 9 & 1 & 0 & 0 & 0 \\
\hline 2. & Sagu Sabu Program is very important for teachers to follow. & 7 & 3 & 0 & 0 & 0 \\
\hline 3. & Sagu Sabu is a very challenging program for teachers. & 8 & 2 & 0 & 0 & 0 \\
\hline 4. & $\begin{array}{l}\text { Sagu Sabu Program leads teachers to be active, creative, } \\
\text { andproductive coursebook writers. }\end{array}$ & 9 & 1 & 0 & 0 & 0 \\
\hline 5. & $\begin{array}{l}\text { Sagu Sabu program is in line with the character of } 21 \text { st- } \\
\text { centuryteachers. }\end{array}$ & 8 & 2 & 0 & 0 & 0 \\
\hline 6. & Sagu Sabu program is easy to follow and implement. & 2 & 7 & 1 & 0 & 0 \\
\hline 7. & $\begin{array}{l}\text { Sagu Sabu program requires self-readiness, adequacy and } \\
\text { completeness of teaching materials, and patience. }\end{array}$ & 6 & 4 & 0 & 0 & 0 \\
\hline 8. & $\begin{array}{l}\text { Sagu Sabu program requires good timing so that the results } \\
\text { canbe achieved properly. }\end{array}$ & 9 & 1 & 0 & 0 & 0 \\
\hline 9. & $\begin{array}{l}\text { Sagu Sabu program must be supported by the } \\
\text { government,related institutions, and schools. }\end{array}$ & 7 & 3 & 0 & 0 & 0 \\
\hline 10. & $\begin{array}{l}\text { Sagu Sabu program can improve teachers' welfare and } \\
\text { enrichtheir knowledge in the form of books in the school } \\
\text { library. }\end{array}$ & 7 & 2 & 1 & 0 & 0 \\
\hline
\end{tabular}


Based on table 2, question 1 shows that $63 \%$ of teachers agree with Sagu Sabu as a very important program for teachers to produce textbooks. Based on question 2, $60 \%$ of the teachers agreed with the program because it was very interesting for them to participate in. Question 3 shows that $62 \%$ of the teachers agree with the program because it is very challenging. Question 4 shows that $63 \%$ of teachers agree with the program because it can lead teachers to be active, creative, and productive writers. Question 5 explains that $61 \%$ of teachers agree with the program because it fits perfectly with the character of 21 st-century teachers. Question 6 shows $53 \%$ of the teachers know whether the program is easy or not for them to follow and implement. Question 7 shows that $60 \%$ of teachers agree that the program requires self-readiness, completeness of the material, and patience to implement it. Question 8 explains that $63 \%$ of teachers agree that the program requires good and regular time management so that all writing targets are achieved. Question 9 shows that $61 \%$ of teachers agree that the program should be supported by the government, institutions, and schools. Finally, question 10 shows that $59 \%$ of teachers do know whether the Sagu Sabu program can improve teacher welfare and enrich school libraries or not.

\subsection{Teachers' Coursebook Productivity before and after the Sagu Sabu Program Implementation}

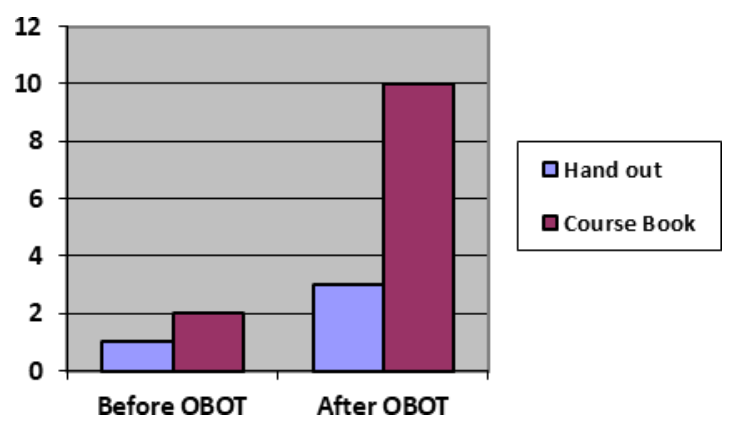

Chart 1. The Comparison of Teachers' Coursebook Production before and after the Sagu Sabu Program Implementation

Chart 1 illustrates that only $7.6 \%$ of teachers wrote handouts and $15.4 \%$ of them wrote textbooks before the SAGU SABU program was implemented. On the other hand, after the Sagu Sabu program was implemented, there was a very significant increase. Only $23.1 \%$ of teachers wrote handouts and $76.9 \%$ of them wrote course books. 
What happens after the Sagu Sabu program is implemented? The activity of writing course books for teachers is well intensified and enhanced. Teachers are asked to prepare teaching materials to be arranged into subject books. This program has become a routine activity that is continuously fostered and monitored by the school's Sagu Sabu program organizer team. All stages of the Sagu Sabu program are carried out intensively and thoroughly, starting from the preparation of teaching materials to compiling according to the curriculum, syllabus, and lesson plans, writing the initial draft, checking drafts according to the content, and rules. prepare appropriate textbooks, edit and revise initial drafts to become final drafts ready for publication, make book covers and other formats, and finally publish drafts in publishers [6], [18], [20]. During the Sagu Sabu program, teachers succeeded in increasing the productivity of textbooks by $76.9 \%$. This is a testament to the success of the Sagu Sabu program. So that the productivity of teacher textbooks increases better. This is in line with the spirit of productivity in writing coursebooks [4], [12].

The impact of the Sagu Sabu program is not only that the number of textbooks has increased, but the quality of the books is also getting better. The quality of the books produced is under and adapted to the anatomy and standard criteria of a good coursebook [4], [15]. The course books they produce have good anatomy: or coursebooks: 1) Foreword, 2) Foreword, 3) Table of Contents, 4) Chapters, 5) Material for Review, and 6) Bibliography. The subject book is well structured so that it fits the criteria as an ideal subject book, for example, 1) greatly helps students in developing their communication skills effectively, 2) encourages students to actively learn and work together, 3) provides a variety of fun questions, 4) contains a variety of questions with a variety of learning strategies, 5) becomes a reference used in learning, and 6) adaptive to current conditions following the era of the internet and digital technology.

\section{Conclusion}

From all the research findings above, it can be concluded that the Sagu Sabu program can increase the productivity of textbooks made by teachers in schools. This program is very helpful in improving the performance and performance of active, productive, and innovative 21stcentury teachers. They gain a lot of experience on how to compose textbooks which they rarely do. They succeeded in making written works from teaching materials, handouts, and modules into standard textbooks with good anatomy. They are proud that their work can be published and become a reference for themselves, their students, and all those in need. That's a big benefit from the SAGU SABU program, which inspires teachers to write their textbooks.

\section{References}

[1] R. Alaydrus, 7 Karakteristik Guru Abad 21, 2917. Retrieved from https://pendidikkreatif.wordpress.com/2017/01/07/7-karakteristik-guru-abad-21/ on October 2, 2019.

[2] BC, The Planning Stage of Writing. BCourse Berkeley Edu, 2019. Retrieved from https://bcourses.berkeley.edu/courses/1357555/pages/b-dot-3-1-the-planning-stage-ofwriting?module_item_id=13261220 on October 2, 2019.

[3] B. Collins, How to Write a Book in 2019: A Definitive Guide for Writer. Become a Writer Today, 2019. Retrieved from https://becomeawritertoday.com/how-to-write-a-book/ on October 1, 2019. 
[4] Eric A. Hanushek, E.A. and Ettema, E. (2017). Defining Productivity in Education: Issues and Illustrations. The American Economist, Vol. 62(2) 165-183. DOI: 10.1177/0569434516688207.

[5] R. Hartono, Improving Students' Translation Products. The $5^{\text {th }}$ ELTLT International Conference Proceedings, 2016. ISBN 978-602-73769-3-9. October, pp. 593-598.

[6] R. Hartono, Implementasi One Book One Teacher Program bagi guru SMA Islam Terpadu Bina Amal Kota Semarang [PowerPoint slides]. Semarang, Indonesia: PkM UNNES, 2019a.

[7] R, Hartono, B. Purwanto, and S, Bahri, One Book One Teacher Program for Upgrading Teachers' Writing Competence (A Descriptive Survey). Unpublished Society Service Project Report. Semarang: Universitas Negeri Semarang, 2019b.

[8] Ihsan, Satu Guru Satu Buku (Sagusabu) Bersama Media Guru, 2019. Diunduh dari http://ihsan.gurusiana.id/article/satu-guru-satu-buku-sagusabu-bersama-mediaguru-5295313

[9] Kompasiana, Panggilan Menulis "Satu Guru Satu Buku", 2018. Diunduh dari https://www.kompasiana.com/thsalengke/5b0e3daacaf7db7850549c92/panggilan-menulis-satuguru-satu-buku

[10] Maslani, Literasi dan Gerakan Satu Guru Satu Buku, 2017. Diunduh dari https://blog.igi.or.id/literasidan-gerakan-satu-guru-satu-buku.html

[11] B. Nurdiansyah, Mari menulis buku ajar, inilah format penulisan buku ajar yang baik [Blog post], 2016. Retrieved from https://www.duniadosen.com/mari-menulis-buku-ajar-g028/

[12] S. Oebaidillah, Tingkatkan Literasi, Guru Diminta Kreatif Menulis Buku, 2017. Diunduh dari http://mediaindonesia.com/read/detail/105878-tingkatkan-literasi-guru-diminta-kreatif-menulisbuku

[13] R.M.S. Putra, How to Write Your Own Text Book: Cara Asyik Mambuat Buku Ajar yang Powerful! Bandung: Penerbit Kolbu, 2017.

[14] S. Rahayu, Guru Penulis, Satu Guru Satu Buku, 2017. Diunduh dari http://www.jurnalasia.com/opini/guru-penulis-satu-guru-satu-buku/

[15] Rappahannock, How to read a college textbook. Rappahannock Community College, 2014. Retrieved from https://www.slideshare.net/rsgrfn/anatomy-of-a-textbook?from_action=save on October 3, 2019.

[16] S. Setiati, Anatomi dan struktur buku ajar [PowerPoint slides]. Pelatihan Buku Ajar Kopertis Wilayah VI. Jawa Tengah, Indonesia: Ditjen Dikti Kemendikbud, 2012.

[17] B. Trimansyah, Catatan Anti Bingung Menulis Buku Ilmiah: Membedah Pedoman Dikti dan LIPI dalam Penulisan-Penerbitan Buku Ilmiah. Jakarta: PT. Inkubator Penulis Indonesia (IPI), 2018.

[18] Trimansyah, B, Editing Pedia: Segala Hal tentang Editing Naskah Yang Perlu Anda Ketahui. Jakarta: PT. Inkubator Penulis Indonesia (IPI), 2019a.

[19] B. Trimansyah, Konversi KTI non buku menjadi buku [Handout]. Jakarta, Indonesia: Inkubator Penulis Indonesia (IPI), 2019b.

[20] B. Trimansyah, Tentang penulisan buku dari hasil penelitian dan sertifikasi penulis buku [PowerPoint slides]. Semarang, Indonesia: UNNES Press. Universitas Negeri Semarang, 2019c.

[21] B. Trimansyah, Penulisan buku ajar [Handout]. Semarang, Indonesia: Jurusan Bahasa dan Sastra Inggris, FBS UNNES, 2019d.

[22] A. Watson, How to get started writing and publishing a teaching book, 2019. Retrieved from https://thecornerstoneforteachers.com/publishing-a-teaching-book/ on October 1, 2019. 